\title{
POLSKIEGO SAMORZĄDU TERYTORIALNEGO DROGA DO NOWOCZESNOŚCI. DYLEMATY OKRESU TRANSFORMACJI
}

\section{POLISH LOCAL GOVERNMENT ROAD TO MODERNITY. \\ DILEMMAS OF THE TRANSFORMATION PERIOD}

\section{Streszczenie}

Polski samorząd terytorialny przebył długą drogę, by stać się integralną częścią systemu władz publicznych. Prawo do samorządu stało się podstawową zasadą towarzyszącą procesom ustrojowej demokratyzacji. Zgodnie z ideą decentralizacji i dekoncentracji powierzono samorządowi terytorialnemu do realizacji istotną część zadań publicznych. Dzięki tym działaniom polski samorząd terytorialny wkroczył na drogę nowoczesności rozumianej jako demokratyzacja ładu ustrojowego i stosowanie w procesie zarządzania państwem europejskich wzorców i standardów.

Słowa kluczowe: samorząd terytorialny; transformacja; decentralizacja; recentralizacja.

\section{Abstract}

Polish local government has come a long way to become an integral part of the public authorities. The right to self-government has become a fundamental principle which accompanies processes of political democratization. According to the idea of decentralization and deconcentration, the local government had to carry out important part of the public tasks. Thanks to these actions Polish local government 
stepped on the path of modernity which is understood as the democratization of the governance body and use of European patterns and standards in the process of state management.

Keywords: local government; transformation; decentralization; recentralization.

\section{Uwagi wstępne}

Droga polskiego samorządu terytorialnego do odzyskania swojej podmiotowości i suwerenności zajęła osiem długich lat, podczas których następowała głęboka i niezwykle złożona systemowa zmiana wszystkich sfer życia publicznego. Procesy przemian rozpoczęte w Polsce w 1989 roku ustaleniami Okrągłego Stołu, w wyniku których w czerwcu 1989 roku przeprowadzono wybory do Sejmu i Senatu, nakreśliły kierunek ustrojowych zmian ${ }^{1}$. W literaturze przedmiotu okres ten określany jest mianem transformacji. Również w kontekście moich rozważań transformacja oznaczać będzie złożony, wielopłaszczyznowy, pełen sprzeczności proces trudnych zmian, nowych konfliktów i społecznie odczuwalnych kosztów. Kształtował się nowy system polityczny, a w jego ramach nowe mechanizmy władzy określanej jako publiczna ${ }^{2}$. Zakładam także, że procesy zmian rozpoczęte w pierwszej połowie 1989 roku nie zostały domknięte i trwają nadal. Zmieniły się tylko zasady wyznaczające kierunek tych zmian. W latach dziewięćdziesiątych ubiegłego wieku była to odbudowa samorządu terytorialnego jako integralnego ogniwa systemu władz publicznych. Następne lata to czas dostosowywania organizacji i działania administracji publicznej, w tym instytucji samorządu terytorialnego, do standardów wynikających z członkostwa w Unii Europejskiej. W kolejnym okresie, już jako członek ponadnarodowych europejskich struktur, podmioty władz publicznych poszukiwały nowych narzędzi realizacji zadań, także tych wynikających z członkostwa we Wspólnotach. Obecnie zaobserwować możemy powrót do działań i zachowań określanych przez jednoosobowy ośrodek politycznej dyspozycji i zastąpienie zasad decentralizacji i dekoncentracji - w oparciu

1 W wyniku porozumień Okrągłego Stołu parlament miał być tylko częściowo powołany w wolnych wyborach. Ustalono, że tylko do Senatu wybory będą całkowicie wolne (Zob. A.L. Sowa, Historia polityczna Polski 1944-1991, Kraków 2011, s. 626-627).

2 Zob. A. Lipska-Sondecka, Transformacja administracji publicznej w Polsce. Od upadku realnego socjalizmu do czlonkostwa w Unii Europejskiej, Warszawa 2015, s. 11. 
o które budowano po 1989 roku nowy model administracji publicznej - recentralizacją rozumianą jako „współczesny powrót do przeszłości”.

Drugie pojęcie zawarte w tytule artykułu to nowoczesność. Postrzegam ją jako proces demokratyzacji ładu ustrojowego z jednej strony i zorganizowanie aparatu administracji państwa w oparciu o europejskie standardy organizacji i działania, z drugiej strony. Podobnie jak dla pojęcia transformacji cezurą był rok 1989, również dla pojęcia nowoczesności są to wybory czerwcowe (1989), które nakreśliły kierunek przemian systemowych. W tym kontekście transformacja i nowoczesność występują równolegle, przy czym kierunek zmian dla zdefiniowania pojęcia nowoczesności, określam jako tworzenie optymalnych warunków rozwoju, w których wszystkie podmioty publiczne, w tym samorząd terytorialny, mają możliwość generowania zmian modernizacyjnych na miarę XXI wieku.

\section{Prawo do samorządu jako demokratyczna zasada państwa prawa}

W dniu 8 marca 1990 roku uchwalono pierwszą po 1989 roku ustawę samorządową, na mocy której gminy stały się podmiotem władzy publicznej, a wybrane w dniu 27 maja 1990 roku rady gmin podjęły się trudnego i odpowiedzialnego zadania organów stanowiących i kontrolnych ${ }^{3}$. Tym samym rozpoczął się nowy okres w historii polskiego samorządu terytorialnego ${ }^{4}$. Jednak batalia o prawo lokalnych i regionalnych społeczności do zarządzania swoimi sprawami trwała kilka lat i doprowadzić miała do zorganizowania samorządu terytorialnego $\mathrm{w}$ oparciu o europejskie wzorce i standardy działania oraz przyczynić się do realizacji zasad i wartości określających demokratyczne państwo prawa. Zmierzając ku europejskim standardom, zgodnie z przyświecającą procesom demokratyzacji ideą decentralizacji i dekoncentracji ustanowiono dwa kolejne szczeble samorządu tj. powiat oraz samorząd w województwie ${ }^{5}$. Z dniem 1 stycznia 1999 roku gmina, powiat oraz samorząd województwa stały

\footnotetext{
Ustawa z dnia 8 marca 1990 r. o samorządzie terytorialnym; z dniem 1 stycznia 1999 r. w wyniku wprowadzenia nowego trójszczeblowego podziału administracyjnego państwa oraz dwóch jednostek samorządu terytorialnego tj. powiatu i samorządu w województwie, ustawa ta otrzymała tytuł ustawy o samorządzie gminnym (tekst jedn. Dz.U. z 2016 r., poz. 446).

4 A. Lutrzykowski (red.), Polski samorzad terytorialny. Europejskie standardy i krajowa specyfika, Toruń 2014, s. 15.

5 Ustawa z dnia 5 czerwca 1998 r. samorządzie powiatowym (tekst jedn. Dz.U. z 2016 r., poz. 814); ustawa z dnia 5 czerwca 1998 r. o samorządzie województwa (tekst jedn. Dz.U. z 2016 r., poz. 486).
} 
się jednocześnie jednostkami nowego, zasadniczego trójstopniowego podziału terytorialnego państwa ${ }^{6}$.

Ustawodawca wyodrębnił samorząd lokalny i regionalny spośród innych podmiotów społecznych, nadając mu osobowość publicznoprawną i powierzając do samodzielnej realizacji istotną część zadań publicznych ${ }^{7}$. Podmiotem samorządu terytorialnego została społeczność zamieszkująca na określonym obszarze, zorganizowana w terytorialny związek samorządowy. Przynależność do takiego związku powstaje z mocy prawa, przez sam fakt zamieszkiwania na określonym terytorium i trwa tak długo, jak długo dana osoba stale tam zamieszkuje. Aktywne angażowanie się w życie wspólnoty samorządowej lub pozostawanie biernym w działalności związku nie ma wpływu na fakt naszego członkostwa lub wykluczenia ze wspólnoty. Powierzonych zadań związek samorządowy nie jest w stanie realizować in pleno, dlatego lokalne i regionalne społeczności powołują $\mathrm{w}$ drodze wyborów organy przedstawicielskie, za pośrednictwem których wykonują nałożone na związek zadania. Tak skonstruowany terytorialny związek samorządowy pozostaje pod nadzorem władzy państwowej, ponieważ jego byt uzależniony jest od woli ustawodawcy czyli państwa.

W wyniku procesów transformacyjnych władza w Polsce została podzielona pomiędzy organy państwowe i inne podmioty takie jak: samorząd terytorialny, zawodowy, samorząd gospodarczy, fundacje, stowarzyszenia, tworząc w ten sposób przestrzeń do zarządzania własnymi sprawami przez zainteresowane i uprawnione do tego instytucje. Samorząd terytorialny spośród wielu innych pozapaństwowych podmiotów okazał się najbardziej predysponowany do rozwiązywania wielu różnorodnych problemów społecznych dużych zbiorowości ludzkich, a prawo do samorządzenia stało się wartością wpisującą się w ogólnie pojmowane zasady wolności i praw obywatelskich. Konstytucyjne umocowanie samorządu terytorialnego jako integralnego ogniwa systemu władz publicznych potwierdziło tezę, że w państwach demokratycznych samorządność jest miernikiem stopnia demokratyzmu władzy politycznej i stanowi istotne źródło siły państwa ${ }^{8}$. Rolę i znaczenie lokalnej i regionalnej

6 Ustawa z dnia 24 lipca 1998 r. o wprowadzeniu zasadniczego, trójstopniowego podziału terytorialnego państwa (Dz.U. z 1998 r. Nr 96, poz. 603 ze zm.).

7 A. Lipska-Sondecka, Administracja publiczna w Polsce na szczeblu lokalnym i regionalnym. Ku europejskim standardom, Bydgoszcz 2011, s. 71.

8 Konstytucja RP z dnia 2 kwietnia 1997 r. poświęca samorządowi terytorialnemu rozdział VII, art. od 163 do 172. Są jednak i takie państwa, w których ustawy zasadnicze nie posiadają przepisów odnoszących się do samorządu terytorialnego np. Norwegia oraz takie, które Konstytucji w rozumieniu 
samorządności w zaspokajaniu i artykułowaniu potrzeb dużych zbiorowości ludzkich dostrzegły także ponadnarodowe podmioty i instytucje, takie jak Rada Europy czy Unia Europejska. Szczególnym dorobkiem w tym zakresie dysponuje Rada Europy, na forum której powstały dwa dokumenty mające ważne znaczenie dla organizacji i działania samorządów lokalnych i regionalnych'. Mam tu na myśli Europejska Kartę Samorządu Lokalnego (European Charter of Local Self-Government) oraz Europejska Kartę Samorzadu Regionalnego (European Charter of Regional Self-Government). Pierwszy dokument EKSL opisuje samorząd nie tylko w kategoriach rozwiązań prawnoustrojowych, ale wyraźnie wskazuje, że realny sens prawa do samorządu wyraża się w rzeczywistej zdolności lokalnych społeczności do zarządzania własnymi sprawami. W podobnym duchu, propagującym prawo do samorządu, sformułowany jest drugi dokument - EKSR, który od momentu podpisania go (1997 rok) nadal nie posiada mocy obowiązującej. Mimo, że pozostaje projektem, jego treść jest potwierdzeniem intencji ponadnarodowych podmiotów do aktywizowania regionalnych społeczności oraz ich władz na rzecz umacniania zasady samorządzenia $^{10}$. Wspólnoty Europejskie także zwracają uwagę na niezmiernie ważną rolę terytorialnej samorządności, która wydaje się być kluczowa w promowanej przez Wspólnoty idei zrównoważonego rozwoju społeczno-gospodarczego. Działalność unijnego Komitetu Regionów, w skład którego wchodzą przedstawiciele organizacji reprezentujących środowiska samorządowe potwierdza założenie, że Unia Europejska szanuje prawa lokalnych i regionalnych społeczności do samorządzenia, a samorząd terytorialny wraz z innymi pozapaństwowymi podmiotami i instytucjami jest nieodłącznym elementem wspólnotowego ładu ustrojowego.

Prawo do samorządu jako ustrojowa zasada zadekretowana przepisami krajowymi i ponadnarodowymi nie jest jednak ostatecznym gwarantem rzeczywistej realizacji praw jednostki do samostanowienia. Miernikiem stopnia funkcjonalności instytucji samorządu terytorialnego jest praktyczna zdolność organów samorządowych i ich aparatu wykonawczego do wypełniania konstytucyjnych i ustawowych zadań. Wciąż bowiem pojawiają się nowe problemy związane z postępującymi procesami globalizacji oraz przybierającymi na

kontynentalnym nie mają np. Wielka Brytania. Nie oznacza to, że władze publiczne w tych państwach nie przestrzegają wartości i zasad utożsamianych z prawem do samorządu.

9 A. Lipska-Sondecka, Prawo do samorzadu jako podstawowa zasada demokratycznego państwa prawnego, [w:] D. Plecka, Z. Osmólska (red.), Administracja publiczna. Wybory samorzadowe 2014, Toruń 2015, s. 12.

10 Tamże. 
sile zjawiskami kryzysowymi. Procesy transformacyjne polskiego samorządu terytorialnego, z tego punktu widzenia, nie zostały więc domknięte. Doświadczenia naszego państwa w zakresie prawnoorganizacyjnych rozwiązań poszczególnych jednostek samorządowych upoważniają do stwierdzenia, że administracja samorządowa będzie nadal musiała mierzyć się z aktualnymi problemami generowanymi nie tylko przez czynniki zewnętrzne, ale przede wszystkim kadencyjno-koalicyjnym charakterem zmian regulacji prawnych w zakresie rozwiązań ustrojowych naszego samorządu. Ujawniające się tendencje ostatnich kilku powyborczych miesięcy (od października 2015 roku) wyraźnie wskazują, że działania o charakterze recentralizacyjnym przybierają na sile i niestety nie widać żadnej szansy na odwrócenie lub przynajmniej zatrzymanie pewnego ciągu zdarzeń, które nieuchronnie zakończyć się mogą powrotem do centralnego modelu zarządzania państwem. Obecna władza konsekwentnie zdobywa i zawłaszcza wszystkie najważniejsze organy i instytucje zbudowane w okresie wielkich zmian ustrojowych w latach dziewięćdziesiątych ubiegłego wieku. Sejm, Senat, Trybunał Konstytucyjny, Krajowa Rada Radiofonii i Telewizji, to tylko niektóre przykłady pokazujące podporządkowywanie konstytucyjnych organów państwa jednemu ośrodkowi politycznej dyspozycji. Działania o charakterze recentralizacyjnym zbliżają się także do obszaru, na którym prawo do samorządu utożsamiane było z demokratyczną legitymizacją władzy oraz naturalnym prawem jednostki do samostanowienia. Praktyczny wymiar tego prawa wyrażał się bowiem w tym, że lokalne i regionalne społeczności posiadały realną zdolność do realizacji powierzonych zadań. Na przestrzeni kilkudziesięciu lat od uchwalenia pierwszej ustawy samorządowej po 1989 roku, praktyczny wymiar tego prawa przechodził swoje lepsze i gorsze chwile, obecnie mamy do czynienia z taką oto sytuacją, że samorządność wyraża się tylko poprzez literalną realizację przepisów ustaw przez samorządowe władze. Prawo określa nie tylko zadania, ale także sposób ich realizacji, nawet w odniesieniu do zadań własnych samorządów. Władze samorządowe zaś są zobowiązane do określonego w ustawach postępowania przy realizacji zadań, nawet jeśli takie działania mijają się z podstawowym i naturalnym prawem każdej wspólnoty samorządowej tj. realizacją dobra wspólnego określonej lokalnej/regionalnej społeczności. A przecież w większości współczesnych demokratycznych państw obywatele są istotnym czynnikiem/mechanizmem w sprawowaniu władzy, co wyraża się w praktycznej realizacji obywatelskich praw $\mathrm{np}$. udziału w wyborach, działalności organizacji 
pozarządowych czy instytucji samorządu terytorialnego, ale także zawodowego i gospodarczego. Stopień realizacji tych praw opisuje pojęcie nowoczesności na miarę XXI wieku. Przyjmując założenie, że współczesne definiowanie nowoczesności oznacza budowanie optymalnych warunków rozwoju, w których wszystkie podmioty i instytucje publiczne będą zdolne do generowania zmian cywilizacyjno-kulturowych możemy stwierdzić, że tylko przemyślane zachowania elit i odpowiedzialne decyzje klasy rządzącej są w stanie sprostać aktualnym problemom i wyzwaniom, przed którymi stanęła polska samorządność.

\section{Uwagi końcowe}

Odbudowa samorządności terytorialnej w Polsce po 1989 roku była niewątpliwie ogromnym sukcesem nie tylko ówczesnych, władz ale także całego społeczeństwa. Dała początek budowie struktur społeczeństwa obywatelskiego i państwa demokratycznego. Dzięki zaangażowaniu i determinacji wielu dziesiątków tysięcy osób udało się zbudować instytucję - najpierw na poziomie gminy, a następnie w powiecie i województwie - która stała się integralną częścią systemu władz publicznych naszego państwa. Na samorządzie terytorialnym spoczął nie tylko obowiązek realizacji zadań, ale także odpowiedzialność za artykułowanie potrzeb i aspiracji rozwojowych lokalnych i regionalnych społeczności. Model prawnoorganizacyjny polskiego samorządu zadekretowany w przepisach krajowych jest także zgodny - generalnie - z europejskimi standardami. Nie oznacza to jednak, że w praktycznym wymiarze spełnia on swoje ustrojowe funkcje. Miernikiem stopnia funkcjonalności samorządu terytorialnego jest realna zdolność samorządowych społeczności do wypełniania powierzonych mu zadań w oparciu o zasadę subsydiarności z wykorzystaniem nowoczesnych form i metod zarządzania publicznego ${ }^{11}$. Zatem samorząd terytorialny jako integralne ogniwo systemu politycznego naszego państwa będzie dokładnie taki, jakie jest nasze społeczeństwo, ,,ani lepszy ani gorszy"12. Najważniejszym zadaniem w kontekście drogi polskiego samorządu terytorialnego do nowoczesności jest obecnie zmiana świadomości, zachowań i postaw polskiego społeczeństwa, czego nie da sie uzyskać ustawami. Poszukiwanie

11 A. Lipska-Sondecka, Transformacja administracji publicznej..., s. 248.

12 J. Regulski, Kilka uwag i refleksji na tle raportu: „Narastajace dysfunkcje. Zasadnicze dylematy, konieczne działania”, Fundacja Rozwoju Demokracji Lokalnej, Warszawa, luty 2013, s. 19, http:// www. frdl.szczecin.pl/manager_pliki/18/Uwagi_o_raporcie_prof_Jerzego_Hausnera.pdf (dostęp: 25.06.2016 r.). 
i wskazywanie najważniejszych wartości społecznych, kulturowych i cywilizacyjnych określających naszą drogę awansu na miarę wyzwań XXI wieku jest najważniejszym zadaniem, któremu muszą sprostać środowiska naukowe. Ich rola w tym zakresie wydaje się być kluczowa.

\section{Literatura}

1. Lipska-Sondecka A., Administracja publiczna w Polsce na szczeblu lokalnym i regionalnym. Ku europejskim standardom, Wydawnictwo MASS, Bydgoszcz 2011.

2. Lipska-Sondecka A., Prawo do samorzadu jako podstawowa zasada demokratycznego państwa prawnego, [w:] D. Plecka, Z. Osmólska (red.), Administracja publiczna. Wybory samorządowe 2014, Wydawnictwo Adam Marszałek, Toruń 2015.

3. Lipska-Sondecka A., Transformacja administracji publicznej w Polsce. Od upadku realnego socjalizmu do członkostwa w Unii Europejskiej, Wydawnictwo ASPRA-JR, Warszawa 2015.

4. Lutrzykowski A. (red.), Polski samorzad terytorialny. Europejskie standardy i krajowa specyfika, Wydawnictwo Adam Marszałek, Torun 2014.

5. Regulski J., Kilka uwag i refleksji na tle raportu: „, Narastajace dysfunkcje. Zasadnicze dylematy, konieczne działania", Fundacja Rozwoju Demokracji Lokalnej, Warszawa 2013, http://www.frdl.szczecin.pl/manager_pliki/18/Uwagi_o_raporcie_prof_Jerzego_ Hausnera.pdf (dostęp: 25.06.2016r.).

6. Sowa A.L., Historia polityczna Polski 1944-1991, Wydawnictwo Literackie, Kraków 2011.

Agnieszka Lipska-Sondecka

Koszalińska Wyższa Szkoła Nauk Humanistycznych 